Matthew W. L Yeung* and Janny H. C Leung

\title{
"You have to teach the judge what to do": Semiotic gaps between unrepresented litigants and the common law
}

\author{
DOI 10.1515/sem-2015-0070
}

\begin{abstract}
The courtroom can be seen as a semiotic space where the practice of signs is institutionalized. There are specific ways to perform signs in court, be they verbal (e. g., turn-taking) or nonverbal (e. g., attire). Legal signs communicate and signify differently than their non-legal counterparts. Laypeople may not be aware of such differences, and may encounter a gap between their expectation and the actual practice of legal signs. This is precisely the case for unrepresented litigants, laypeople who go to court without legal counsel, whose understanding and practice of signs usually differ from legal ones given their limited exposure to legal knowledge and culture. This paper examines unrepresented litigants' lay practice of signs in Hong Kong courtrooms, and analyses how it clashes with that used by legal professionals. Our data consist of courtroom observations of 54 Cantonese case managements and 13 Cantonese trials in district courts in Hong Kong, 10 interviews with unrepresented litigants and 6 relevant judgments. The paper shows that the differences in the use of semiotics often place laypeople as out-group members of the law and may limit their access to justice. Our analysis will contribute to an understanding of laypeople's behavior in the courtroom, which in turn bridges the communication gap between laypeople and legal professionals in common law jurisdictions.
\end{abstract}

Keywords: signs, legal-lay expectations of justice, unrepresented litigants, legal language, courtroom discourse

\section{Introduction}

The dyadic model of the sign by Saussure defines a sign as having two components - a signifier (significant) and a signified (signifié). The former refers to the form that a sign takes whereas the latter refers to the concept that a sign represents. What

\footnotetext{
*Corresponding author: Matthew W. L Yeung, School of Professional Education and Executive Development (SPEED), The Hong Kong Polytechnic University (PolyU); University of Hong Kong, Hong Kong, People's Republic of China, E-mail: Yeungmatty@gmail.com Janny H. C Leung, University of Hong Kong, Hong Kong, People's Republic of China, E-mail: janny@cantab.net
} 
troubles communication is that the relationship between a signifier and a signified is largely arbitrary (Saussure 1983 [1916]). As Chandler notes, "signs ... have no intrinsic meaning and [things] become signs only when we invest them with meaning" (Chandler 2002: 13). The meaning of signs is subject to the space in which they are situated. Courtroom as a semiotic space offers an example of how signs are institutionalized through specialized usage and may therefore be impenetrable to an outsider. This is precisely the case for unrepresented litigants, laypeople who are party to a trial without legal counsel, whose understanding and practice of signs usually differ from legal ones given their limited exposure to legal knowledge and culture. This paper examines unrepresented litigants' lay practice of signs in Hong Kong courtrooms, and analyses the differences between legal professionals and the laypeople in their expectation and interpretation of courtroom interactions. Such differences may limit laypeople's access to justice and their perception of justice.

Unrepresented litigation is a useful lens through which the specificity of signs in common law and its challenges to lay-legal communication can be examined. As Moorehead and Sefton aptly observe,

[b]ecause of the substantive and procedural naivety of unrepresented litigants, the traditional roles of judge (passive arbiter) and court staff (passive administrator) are challenged, as are some of the central conceits of an adversarial paradigm. The usual rules and assumptions governing civil and family procedure do not work, or do not work as well: unrepresented litigants do not know or understand the prevailing paradigms of court practice and their behavior is naturally, as a result, at odds with the normal practices of a court. (Moorhead and Sefton 2005: 265)

Reports from different parts of the world suggest that unrepresented litigants often make procedural errors (for example, they do not know how to properly object to evidence; see Klein 2010) and do not demonstrate knowledge of substantive law (for example, they have difficulty determining what evidence is relevant and reliable; see Lewis 2007). Unrepresented litigants in Hong Kong have been found to share the same plight and in particular, they have little idea as to how to compile documents, when to summon witnesses and what to highlight in their case (Kelly and Cameron 2003; Kelly 2005; Kelly et al. 2006; Ng 2009). As a result, judges and the opposing party are sometimes compelled to take over some of such responsibilities to facilitate the trial. Despite the help they get, unrepresented litigants' unfamiliarity with legal semiotics may continue to place them at a disadvantaged position. It is important to ask then - how do laypeople deal with legal semiotics and how do they draw on, if any, lay semiotics to help them understand the law?

Hong Kong is a suitable site for such investigation for two reasons: (1) its rising number of unrepresented litigants, and (2) its relatively recent bilingual policy that changed the medium of legal communication. Official statistics shows 
that $35 \%$ of civil trials in High Court and $55 \%$ of civil trials in District Court involved at least one party of unrepresented litigants in 2009 (Judiciary Administration 2010). One potential trigger for the increase in self-representation is the change of legal language(s) following the handover of Hong Kong in 1997. As a colonial import from Britain, the common law was mostly conducted in English during much of the colonial rule (1841-1997). Chinese ${ }^{1}$ was introduced as another official language, with an equal status, shortly before the change of sovereignty. Since the first language for the majority of Hong Kong citizens is Cantonese Chinese, the policy has the potential to extend their access to justice. Yet, the lifting of the language barrier does not address all the communication problems faced by unrepresented litigants. There is a need to look into the nature of such problems, and the study of semiotics may provide an illustrative angle into the examination.

\section{Differences between legal and lay expectations of justice}

In order to examine the aforementioned questions, data were collected through courtroom observations and interviews with unrepresented litigants in Hong Kong. From September 2012 to August 2013, 54 Cantonese case managements and 13 Cantonese trials were observed in district courts; 9 unrepresented litigants were briefly interviewed and 1 unrepresented litigant was interviewed in detail with recordings. 6 of the relevant judgments were also obtained for analysis. All of the cases observed involved at least one unrepresented party and they were all civil litigations.

Since courtroom transcripts are generally accessible only to parties of a trial, the data reported below are based on the notes jotted during observations. The data therefore are not suited for detailed discourse analysis but they provide a good illustration of how unrepresented litigants interact with various parties in court, and how a divergence between legal and lay expectations of the law may be revealed from their contact with the court. The interview data will provide explanations of their courtroom behavior by revealing how they approach the law.

1 The written form of Chinese is also known the Standard Chinese, whereas the oral form is predominantly Cantonese in Hong Kong, a dialect widely spoken in Guangdong province. 
The data indicate that unrepresented litigants' use of language, manner of advocacy and ideology of litigation are different from that of legal personnel. Each of these areas will be elaborated in the following.

\subsection{Nonverbal signs}

From the moment a person walks into the courtroom, s/he is already expected to behave according to courtroom etiquette, for example standing and sitting at the right time and place. These conventions are well-known to legal personnel but are the mostly unwritten practice of common law (Wilkinson et al. 2007; Clarke 1991). These conventions may not be intuitive to laypeople who have limited exposure to the semiotics of the courtroom. Yet, an underlying dilemma is that the law operates in its own semiotic world that expects its participants to know the rules of the game, e. g., courtroom etiquette and courtroom procedures. Anyone who does not comply with the rules may undermine the efficiency and fairness of litigations as well as the respect and dignity for the court (Clarke 1991). In order to avoid such situations, various jurisdictions such as the United States, Australia, and Canada have realized the need to provide clear guidance to laypeople and published guidelines on courtroom etiquette (Magistrates Court of Tasmania, Australia 2014; Provincial Court of Newfoundland and Labrador, Canada n.d; United States Bankruptcy Court Southern District of Illinois n.d).

In Hong Kong, the only visible displays that provide some guidance to courtroom etiquette can be found on the doors of the courtrooms. On each door, there are three signs that outline forbidden behaviors, i.e., no eating, talking, or using mobile phones. Most of the observed unrepresented litigants seemed to have paid attention to the signs. One unrepresented litigant took a phone call when it rang loudly in court, and the judge reprimanded him for disturbing the court and also reminded him of the judge's power to put him under arrest. The unrepresented litigant may be unaware that bringing the social habit of using mobile phones, including a quick response to end a phone call, into the courtroom may amount to the contempt of court. According to CAP336 District Court Ordinance 48B Contempt of Court, ${ }^{2}$ a judge has the power to punish any acts that obstruct the administration of justice. The situation may

2 In Hong Kong, CAP336 District Court Ordinance 48B Contempt of Court states that, a judge has the powers of a judge of the Court of First Instance to:

(a) punish for disobedience of a judgment or order of the Court; or

(b) punish for breach of undertakings; or

discipline or punish for breach of a duty imposed upon a solicitor by rules of court. 
be worsened by the fact that there is an absence of guidelines on standard courtroom etiquette, as commonly identified in various jurisdictions before (Clarke 1991). Hong Kong is no exception. Under such circumstances, it seems only normal for laypeople to behave differently from professional advocates, but the question remains - to what extent does the court allow laypeople to deviate from expected behavior? The two examples below suggest that the court exercises its discretion and tends to be lenient with laypeople's deviated behavior.

Some common behavior from unrepresented litigants, as observed in Leung's (2015) courtroom observation in Hong Kong, include cluelessness as to when to sit, speak or use body gesture. In one of the trials we observed, a judge had to remind the unrepresented litigant to: "Stand up when you are speaking. That is a rule in court." Judges regard rising as necessary for maintaining judicial decorum, since it is a "physical gesture of respect for ... the sovereign" (Clarke 1991: 963). Yet, the symbolic meaning behind the gesture remains obscure to unrepresented litigants. No explanation is offered in the official reference texts that aim to prepare unrepresented litigants for civil litigations by the Hong Kong government. It may not be important for unrepresented litigants to know the symbolic meaning, but such knowledge is the basis of courtroom conventions that preserve the professionalism and power of the court (see Clarke 1991).

Another noted example is the act of bowing which is also "a traditional way of indicating mutual respect" (Magistrates Court of Tasmania, Australia 2014). In common law jurisdictions, it is often expected that one rises and bows to the judge when he proceeds to the court from the backdoor. This is usually signaled by three knocks on the door by the judge before his entrance, and also by the judicial clerk's announcement of “court." Although unrepresented litigants generally noticed that they had to stand up in this case, some litigants that we observed did not foresee the bowing, and after a few seconds' delay, they usually nodded gently instead. It is relatively easy for laypeople to observe and follow such practice as it resembles the manner of a social encounter in which one returns a bow to another as greeting.

Yet, institutionally specific practice is less easy to grasp. For instance, it has been observed that during litigations, legal personnel all bowed to the judge in the hallway each time they wished to walk in or out of the courtroom. This is to attribute reverence to the court, and enhance its public image (see Clarke 1991). On the other hand, most unrepresented litigants we observed walked freely between their seats and hallway without any gesture. They might have presumed that bowing at the beginning of a trial would suffice, just like how greeting is usually done once and for all at the beginning of a 
social encounter. In either case, it shows that the meaning of everyday practice of signs is different from the legal practice of signs.

\subsection{Lay advocacy strategies}

Unrepresented litigants have been found to readily engage in quarrel with the other party in court, but they may not be ready to present a legal argument when they are expected to (Leung 2015). Unrepresented litigants' courtroom behavior is not just indicative of their advocacy strategy, but also how the court exercises control over unrepresented litigants.

"Emotional" is a word that most legal personnel would use to describe Cantonese litigants in court, including unrepresented litigants ( $\mathrm{Ng} \mathrm{2009:5).}$ While professional advocates must keep their emotion in bounds (Boon 1999), unrepresented litigants seem to use display of emotion as a strategy to convey their arguments. A rather extreme example to illustrate this from our observations was the physical act of disagreement. Apart from frequent finger-pointing, an unrepresented litigant banged a torchlight loudly on the table and then pointed it at the witness and shouted 我照住你 (My light is on you) in the middle of the other counsel's cross-examination of the witness. His intention was to coerce the witness to speak the truth. He may have drawn on popular culture to help him understand the questioning process in an institutionalized setting. His act resembled an often portrayed scene in local soap operas where a police officer shines a bright light at the suspect during interrogation, demanding him/ her to confess. In addition, the use of torch also conjures up the image of a talisman in Chinese literature and culture called 照妖鏡 (a demon-revealing mirror). In one of the four major Chinese classics 西遊記 (The Journey to the West), the true identity of a demon in disguise is revealed in the demon-revealing mirror or through light reflected from the mirror (see Luo 1987). The unrepresented litigant may have adopted such symbolic meaning of light in his act. Yet, neither the act nor its symbolism fit into the semiotics of the common law courtroom. Instead, it disrupted the flow of litigation, and may even be seen as a harassment of witness as it may cause emotional distress on the witness (see Rhines 1995).

More often than not, however, unrepresented litigants' emotions are channeled through their use of language and tone. Name-calling or accusation (Leung 2015) for instance is commonplace. Phrases such as 大話精 (literally 'lying monster,' roughly equivalent to 'barefaced liar'), 賴皮 (literally 'blame the skin,' referring to shedding responsibility), 大話連篇 ('series of big lies'), 全無道德責任 
('no sense of moral responsibility'), 明顯揑造事實, 作出虛假陳述, 誣蕾本人 ('obviously fabricated the facts and made false statements to frame me') were only a few of the noted examples of how unrepresented litigants added color to their speech. They might have used these unsubstantiated derogatory or accusative phrases due to an uncontrollable burst of emotion. Alternatively it may be seen as a tactical reiteration of their position by immediately rebutting any unfavorable statements, a social strategy that often takes place in daily arguments. However, both the content and language of their assertions are at odds with legal conventions. Clarke (1991) reckons that derogatory remarks may not only derail laypeople's arguments but also "[distract] the decision-maker's collection of information, [disrupt] the flow of the proceedings, and [cause] inefficiency in court proceedings" (997). This is why professional advocates are taught to never "make ... an allegation which is intended only to insult, degrade or annoy the other side, the witness or any other person" (Sherr 1993: 95). This shows how socially meaningful phrases seemingly useful in everyday arguments translate into signs that are meaningless, offensive, and even detrimental to their case when they are re-semioticized or recontextualized in law.

Sometimes unrepresented litigants also use foul language in court. In one case, a 70-year-old unrepresented litigant with primary school education repeatedly used foul words as intensifiers when answering questions by the lawyer and the judge; an example is given below:

Excerpt 1: the lawyer $(L)$ questioned the unrepresented litigant $(U)$ on a monetary dispute

Original

English

$1 \mathrm{~L}$ : 朱先生, 請問你在 2003 年 6 月 18 Mr. Chu, did you receive the twenty

日有友收到原告人比返你 2 萬 5 千 five thousand dollars from the plaintiff 蚊呢?

$\mathrm{U}$ : 你收豩啦你! on $18^{\text {th }}$ June, 2003? You shut your face!

Facing a standard question about facts, the unrepresented litigant unexpectedly asked the lawyer to shut up using a rather rude Cantonese colloquial phrase 收哆 (line 4). The character 嘐 originally denotes tea (Hutton and Bolton 2005). In Cantonese culture, there is a saying 口水多過茶(胗) ('your saliva is more than tea') that describes a person who talks too much when drinking tea in a Chinese restaurant. The unrepresented litigant may have wanted to signal to the lawyer that she had already asked too many questions. In daily argument, such a provocative phrase may intimidate the other party from further pursuit. Yet, in the court setting, verbal vulgarity is out of place; 
he was also under vow to answer all questions with regard to what he knew, a legal obligation that he must fulfil as a witness.

Excerpt 2: the judge (J) helped the lawyer ask the unrepresented litigant $(U)$ the whereabouts of some money

Original

English

$1 \mathrm{~J}$ : 咁你有友收返啲錢呀? Did you collect the money back?
$\mathrm{U}:$ 收撚左啦
Fucking collected already
J: 咩呀?
What?
$\mathrm{U}:$ 收左啦
Collected already

As the questioning process continued, the judge took over from the lawyer and pressed the unrepresented litigant for a clear answer. However, a Cantonese obscene term 撚, which refers to the male genital (see Hutton and Bolton 2005: 246), was inserted as an intensifier into the answer. Perhaps surprisingly, the judge did not criticize his language use in either case. The judge simply reminded the unrepresented litigant to be more "polite." Profanity may amount to contempt of court ${ }^{3}$ (Wilkinson et al. 2007). But this is all subject to the judge's discretion, and the judge's lenient treatment of the mentioned case suggests that the judge may adjust his expectation of courtroom behavior from laypeople, possibly giving consideration to factors such as their age and education.

The use of profanity may further reveal how laypeople understand an adversarial trial. An adversarial trial in common law denotes two things - (1) an attitude where two parties are adversarial to each other, and (2) a platform where two parties compete and convince the court with their respective arguments. An adversarial attitude however does not have to be expressed emotionally; in fact it has been argued that emotion is the least useful element in litigations because it may leave bad impressions on the fact-finders and bring negative impacts to the case outcome (see Evans 1993; Wilkinson et al. 2007). This seems in contrast with the idea of dispute in the social world where an adversarial attitude often presupposes a quarrel with emotional accusations and interruptions. Local soap operas have exploited such social meaning of adversariness by dramatizing how legal personnel are hostile to each other, e.g., shouting “objection” to interrupt the other party's speech (see Apple Daily 2012).

3 In Hong Kong, CAP336 District Court Ordinance 48B Contempt of Court states that, a judge has the powers of a judge of the Court of First Instance to:

(c) punish for disobedience of a judgment or order of the Court; or

(d) punish for breach of undertakings; or

discipline or punish for breach of a duty imposed upon a solicitor by rules of court. 
Such television programs, likely to be a source of the cultural imaginary of the legal system, might have given laypeople a false impression of how meaning is negotiated in the courtroom. However, in an actual courtroom, the portrayed manner may come at a cost. As the judge warned the above unrepresented litigant,

we are here to reason, not to take it personal on one another. The provoking scenes on TV are misleading you, teaching you something wrong. Don't ever learn from them. They are negative examples. The court is not a place for adversarial attacks. If you keep on scolding at will, I may rule contempt of court against you.

The judge's comment neatly highlights how an adversarial trial seems to embody different senses for laypeople and professional advocates - where the former centers on the manner of presentation, while the latter on the platform for competing legal reasoning.

\subsection{Lay cross-examination skills}

Equally important to advocacy, apart from manner, are the skills in questioning witnesses and deconstructing the other story. Yet, unrepresented do not usually make references to exhibits, quote the exact page number of document bundles or even pose questions to witnesses in cross-examination (Leung 2015). Leung (2015) suggests how some unrepresented litigants may not appreciate the purpose of cross-examination. Indeed our data suggest that unrepresented litigants tended to seize every opportunity to narrate their side of story, not through questioning the witness but through dominating the discourse. This may reflect underlying confusion of the purposes of legal procedures - particularly between cross-examination and opening statement. It is questionable whether the institutionalized practice of language in the courtroom is penetrable to laypeople at all.

Such strategy used by lay litigants may alter the existing courtroom dynamics. In common law, (cross)examination is characterized by a specific turn order and type of turn. Minimal pair, namely question and answer pair, is the expected form of interaction. Atkinson and Drew (1979) call the interaction "the A-B-A-B turn," as it is organized in such a way that the (cross)examiner is expected to ask a question (A) in anticipation of an answer (B) from the witness. The type and order of turntaking symbolize the power relationships in court, in that the (cross)examiner is empowered to control the types of questions (i. e., open or closed questions) to be posed to the witness, while the witness is obliged to answer. Yet, unrepresented (cross)examiners' treatment of turn-taking gives rise to a different interactional order. 
This can be seen from the following case in which the plaintiff agreed to rent an apartment for two years to the late owner (Mr. Lee) of the company, but since Mr. Lee vacated the premise after 8 months without the plaintiff's consent to terminate the lease, the plaintiff sued the company, which was the lessee, for compensation. As Mr. Lee passed away not long after he had left the premise and he had entrusted the defendant as the shareholder and chairperson of the board before his death, the defendant had the responsibility to be tried on behalf of the company.

Excerpt 3: The unrepresented defendant (D) cross-examined the witness (W) by narrating his own story, until the judge $(J)$ intervened in their interaction. Original English

1 D: 我都唔係個租客,啊李先先係。你追 I was not the tenant-Mr. Lee was. 我無用家,我只不過係個股東,同理 There is no point of coming after me. I 間公司都執左啦, 我根本唔知咩事。was just a shareholder (of the company), and the company has already folded. I don't even know what

5

$\mathrm{W}$ ：點會唔關你事。或者我地睇下個合 約嘅第三條,個度講到明你公司要負 責家嗎!

10 D: 咁間公司都執左啦！

$\mathrm{W}$ ：但係你答我你係咪間公司負責嘅股 東呀?

$\mathrm{J}$ : 你係係度比證據,唔係問問題家。 happened.

How could this be none of your business. Maybe let us look at the third clause of the contract. It says that your company is responsible for it! The company has already folded! But tell me if you are the responsible shareholder of the company? You are here to give evidence, not to ask question.

The unrepresented defendant (cross-examiner) took the floor to state his views on the case (line 1-5) instead of posing any question. This gave room for the witness (also as the plaintiff) to not only give comments, but also to take control to direct the cross-examiner to read the contract (line 6-9). The usurpation of power further took place when the cross-examiner again responded without asking a question, and this allowed the witness to initiate a turn to question the defendant (cross-examiner; line 11-12) as if she was the actual cross-examiner. A sketch of the above discourse illustrates how the preallocated roles may sometimes be reversed when unrepresented (cross)examiners left the floor open. It is such alteration of the A-B-A-B turn that often creates opportunities for parties to engage in quarrels. This also suggests 
that unrepresented litigants may be too focused on their dominant roles as either plaintiff or defendant that they are unaware of the obligations they have to take up in other roles during litigations, i. e., cross-examiner or witness.

Some observed unrepresented litigants coped with cross-examination with different strategies, and the use of hypothetical question is one such example. Hypothetical question is sometimes used to examine the logical boundaries of evidence (Boon 1999). It is usually performed on a witness who has no first-hand information on factual details but his/her opinion may be of help to the case, i. e., expert witness (Schachner and Quittner 2000). Therefore, hypothetical questions may be posed to expert witnesses but not to lay witnesses. Some unrepresented litigants we observed, however, were not aware of this and they repeatedly asked lay witnesses to comment on their hypothetical scenarios. For example, in a lease dispute similar to Mr. Lee's case, the defendant left the premise two months after signing the one-year lease without compensating the plaintiff, and he was subsequently sued for the breach of contract. In crossexamination, the unrepresented plaintiff posed several hypothetical questions to the defendant: "Suppose you rented the apartment to a person for a year but he took off after two months, do you think it is fair that ..." and "Suppose that you have a company that rented a place to a person ..." In everyday semiotics, hypothetical scenarios are often created to induce deductive analysis of a problem. Hypothetical questions may be posed to expert witnesses, so in a sense lay semiotics is not entirely incompatible with legal semiotics, but laypeople may be confused as to when certain semiotics may be deployed.

Another strategy used by unrepresented litigants that we frequently observed is the use of repetitive questioning. Lawyers may use repetition to emphasize a point by repeating key words and varying sentence structure (City Law School (London, England) 2010; Boon 1999). On the other hand, unrepresented litigants might not be as skilled in reformulating questions. For instance, one unrepresented litigant asked the same question four times without any rephrasing, and the judge had to remind him to stop repeating the question because the witness had already provided the answer. The unrepresented litigant might have hoped to obtain a more favorable answer to his question through repetitions. Repetitive questioning may be a strategy to induce a slip of the tongue from the witness so that his/her incoherent account can be used against the opposition side's story. Such strategy in daily argument is often one of the most direct and frequent forms of confrontation that aims to compel the other side to agree with the proposition. The legal perspective however remains doubtful on the effectiveness of repetitive questioning. There are some judges who even perceive the relentless pursuit as "rude" 
and "damaging" because it may leave a bad impression on the jury and cause prejudice to the case (Clarke 1991: 976-977). In order to induce a favorable answer, professional advocates will approach the witness with different sets of questions from different directions (Sherr 1993). This comparison suggests that unrepresented litigants' semiotic approach to eliciting answers from the witness may be more direct, whereas professional advocates are more skilled in guiding the witness or their approach is simply less confrontational in a sense.

\subsection{Laypeople's legal reasoning}

Given their inexperience with legal semiotics, unrepresented litigants can hardly be expected to know how to make a legal argument and support it with reference to precedents. It is suggested that the first step to prepare for a case is to develop a case theory by looking into the relevant law and evidence (Boon 1999; Ross 2005; Sherr 1993). As McElhaney (McElhaney 1987: 48) notes:

The theory of the case is the basic, underlying the idea that explains not only the legal theory and factual background, but also fits as much as evidence as possible into a coherent and credible whole. Whether it is simple and unadorned or subtle and sophisticated, the theory of the case is the product of the advocate. It is the basic concept around which everything else revolves. (McElhaney 1987: 48)

Given the importance of case theory to litigation, one crucial question in our investigation is how laypeople theorize their case.

In our data, only one unrepresented litigant specifically referred to a legal principle based on precedent. This was a lease dispute case, in which the plaintiff after signing a one-year contract refused to move into the premise because the landlady (defendant) declined to fix the water heater, and the plaintiff therefore hoped to terminate the lease and retrieve the rent deposit. The unrepresented plaintiff argued that since the defendant was unreasonable in refusing to perform the repair, by the doctrine of repudiation (悔約原則) in Funfair Co Ltd $v$ Wong Lui Wing, the lease should be invalidated. Repudiation refers to a rejection or refusal to perform a duty of the contract in the future, which grants the promisee the right to treat it as a breach of contract for lawsuit (Garner 2009). Perhaps surprising to the plaintiff, the judge rejected outright the application of the principle to the case and said that the plaintiff's interpretation was "incorrect” and "against her own case." A detailed explanation was given in court and in the judgment: 
According to the Court of Appeal in Funfair Co Ltd v Wong Lui Wing [2007] 3 HKLR 609, lease is also a kind of contract, and unless stated otherwise in the contract, the contract cannot be terminated unilaterally by any party. Although the doctrine of repudiation also applies to contractual lease, there has to be an acceptance of repudiation by the other party. Since lease is a contract of land, both parties are entitled to enforce specific performance. Unless the landlady is wholly unreasonable in enforcing the lease, the landlady has the right to claim her rent from the tenant.

Since repair service was not included in the lease, the plaintiff had no right to enforce such a performance.

The unrepresented litigant seemed to only understand part but not all of what the doctrine is about. Yet, she was convinced by her reading that the doctrine of repudiation was applicable, because the case partially fulfilled the conditions of the doctrine. She insisted on her opinion even after the judge's explanation. A lay reading of the law may inform the unrepresented litigant that the doctrine was at least somewhat relevant and therefore applicable, but the legal semiotics sees it otherwise, as a legal principle is either applicable or not at all.

\subsection{Expectations of judicial roles}

Upon encountering unfamiliar legal semiotics, a lot of litigants we observed turned to the judge for help. In one recorded interview, an unrepresented litigant shared his observation that

\footnotetext{
a lot of people, including me at first, would think that if you tell your story to the judge, the judge would help you, but actually the judge would not. Quite to the opposite, you have to teach the judge what to do. If you pay attention and go to a few more trials, you will know that lawyers would usually say, I'm quoting this ordinance and please rule the case ... The judge would not go to search for ordinance for you and decide whether you win or lose. This is a misconception harbored by many people.
}

According to the sporting theory, the common law is an adversarial game in which judges serve as an umpire, playing a passive rather than proactive role in litigations (Wilkinson 2000). It is the duties of both parties to convince the judge with their respective legal arguments by collecting and presenting relevant evidence in designated procedures. This contrasts with what laypeople may expect - that judges would be more inquisitorial and investigative. 
One expectation unrepresented litigants may have towards judges is that procedural guidance will be given. Judges do indeed spend time - somewhere between 20 to 40 minutes in trials we observed - to explain legal procedures at the beginning of a trial, as if they were legal educators. The "lecture" usually includes the components and flow of litigation, the contrastive functions of procedures (e.g., opening statement and testifying) and some basic advocacy skills (e.g., asking questions one by one). However, the instructions do not seem to be very effective in that most unrepresented litigants still required constant help from the judge on what to do. Reminders are especially needed when it comes to the manner of interaction. In order to get his message across, one judge we observed used metaphors from the social world: "The court is not City Forum (城市論壇), wet market (街市), or one-voice room (一言堂).” City Forum is a public forum where public figures and citizens gather to discuss current issues in Hong Kong, but the frequent interruptions and shouting from divergent parties dub the forum as chaotic and noisy. Such descriptions apply even to a greater extent to wet markets where vendors talk in their loudest voice to sell food and customers squeeze into the crowd to bargain for a good price. As for one-voice room, it was originally a sign put up by old stores to forbid negotiation but now it signifies the lack of democracy in which a place is ruled by the voice of one man alone (Luo 1987). The respective emblems of the three places as disorderly, clamorous and dominating can be seen as resources which the judge exploited to set comparisons with the orderliness and solemnity the court deserves.

Legal advice is also sometimes expected from judges. Judges may offer advice when unrepresented litigants do not know the merits of their case (Cameron et al. 2006). Our data further suggest that legal advice also appears necessary when unrepresented litigants struggle to weigh their potential options in hand. In the following case, the unrepresented plaintiff was not satisfied with the service provided by a yacht club, and he protested against it by refusing to pay the membership fee. The yacht club calculated the owed membership fee using compound interests, and also terminated his membership. The unrepresented plaintiff sued the yacht club for taking such actions, and demanded the reinstatement of his membership and a re-calculation of the debt using simple interests. At the beginning of the trial, the opposing counsel offered a settlement that not only covered but exceeded the expectation of his claims, which included the reinstatement of his membership, a calculation of the debt without any interest, and a waiver of the counsel's fees. 
Excerpt 5: The unrepresented plaintiff $(P)$ discussed with the judge $(J)$ about his claims in relation to the settlement

\section{Original}

1 P: 咁初期我個 claim, 佢地比左個 counter-claim, 但我都再比左個 counter-counter-claim. 咁我可 唔可以追討我係友左個會藉個

5 陣時嘅損失?

J: Counter-claim 係對個 original claim 左作出嘅, 你係唔可以加 碼家嗎。我唔應該講的都要 講。法庭係講啲量化嘅野。你

想追個啲野可以量化到嗎? 如 果唔得, 法庭會比個象徵式嘅費 用 100 蚊,以前比 1 蚊。對方已 經唔收訟費。其實,係你唔啱,你 用唔交會費來你投訴,係法律嘅

20 角度係你唔啱 ... 律師費其實係 三十幾萬。或者你唔會介意,但 係咁好嘅條件。我地不如休庭, 你地傾一傾?

25 P: 咁如果我唔同意呢?

$\mathrm{J}$ : 我係納稅人比錢的,公帑話唔需 要進行呢個審訊,但我唔鐘意

「霸王硬上弓」。

\section{English}

When I first filed the claim, they filed a counter-claim, but after that I also filed a counter-counter-claim. Can I ask for compensation for the period I lost the membership?

Counter-claim is made based on the original claim and you can't increase the amount (of compensation you seek). I shouldn't say what I'm about to say. The court talks about things that can be quantified. Can you quantify the stuff you are after? If you can't, the court will award you a nominal cost of one hundred dollars. It used to be only one dollar. They already waived the litigation fee. Actually, from the legal point of view, it is your fault that you complained about the club by refusing to pay the membership fee ... The counsels' fee would amount to more than three hundred thousand dollars. Maybe you don't care, but the offer is really good. Why don't we adjourn the court for you two parties to talk about it? What if I disagree? I'm paid by tax payers and the pubic fund says that this litigation is not necessary, but I wouldn't prefer to force a decision upon you.

In addition to offering procedural advice, the judge proceeded to evaluating the settlement offer for the litigant. The judge's behavior may have deviated from the expected passive role of common law judges, and also from the impression that judges rarely lecture defendants in court (Mileski 1970-1971). 
However, the departure was arguably essential for the unrepresented litigant to understand the (de-)merits of the case so as to expedite the litigation. It may help clarify laypeople's understanding of the law by outlining how a case proceeds within its semiotic legal framework.

Last but not least, since unrepresented litigants have difficulties in formulating questions in cross-examination, they sometimes expect judges to relay the message to the other party on their behalf. This sometimes transforms the judge to be a messenger and an interviewer. Instead of the dyadic cross-examiner-andwitness pair, there is an emerging triangulated interaction between judge, crossexaminer and witness where the judge helps reformulate the questions (Leung 2015). This can be seen from the mentioned case about the provision of repair service to the lessee (see laypeople's legal reasoning). The unrepresented plaintiff argued earlier on that the unrepresented defendant never provided any shoe cabinet nor repair service. In the following, the unrepresented defendant tried to counter argue such a claim.

Excerpt 6: The unrepresented defendant (D) cross-examined the witness $(W)$ with the help of the judge (J)

\section{Original English}

1 D: 我個櫃呢一早已經係 My shoe cabinet has always been there.

度。

J: 你同意成唔同意個鞋櫃 ((turned to the witness)) Do you agree that the 已經係度? shoe cabinet has always been there?

W: 個陣我有仔細咁睇。I I didn't pay attention to it then.

$5 \mathrm{~J}$ : 咁你即係同唔同意個鞋 So do you agree or not agree that the shoe cabi櫃已經係度?

$\mathrm{W}$ ：唔同意。 net has always been there? No.

As shown, the unrepresented defendant simply made a statement about the shoe cabinet instead of asking the witness about it (line 1), so the judge assisted by relaying the message to the witness in a question form (line 2-3). In particular, the judge repragmatized the statement into a polar question that would produce readily digestible facts. When the witness's answer did not conform to the question type (line 4), the judge restated the question to signal that the answer can only be either positive or negative. The unrepresented defendant may not have been aware of her duty as a cross-examiner and expected the judge to fulfil all the procedural requirements as she narrated her story (line 1). Narration may be unrepresented litigants' strategy to reinstate their position, and such emphasis on narratives shows how they often see their own words as 
self-sufficient evidence (i. e., declaring statements). This is in contrast with how professional advocates evaluate evidence - they focus on oral testimonies from third parties for objective evidence (i. e., asking questions). Since the common law credits the latter rather than the former approach, unrepresented litigants will be disadvantaged to a certain extent by their way of presenting and evaluating evidence. For the sake of justice, judges thus sometimes take over their position as a cross-examiner. Yet, if this takes place too often, judges may deviate from the presumed passive role too far, which may undermine the judicial impartiality.

\section{Conclusion}

The above analyses have illustrated the potential semiotic differences in the treatment of the law between laypeople and professional advocates. Laypeople seem to draw on lay semiotics from everyday life to help them understand legal semiotics, but sometimes the attempt to reconcile the differences between the two semiotic systems may not be successful.

This study has highlighted courtroom decorum and interactional practices that unrepresented litigants seem to have difficulty with in Hong Kong courtrooms. Such difficulty may be attributable to unwritten rules of the common law tradition (Clarke 1991). Overseas experiences from American, Australia and Canada suggest that an explicit guideline is needed so that legal semiotics can be properly propagated to laypeople coming into contact with law (Magistrates Court of Tasmania, Australia 2014; Provincial Court of Newfoundland and Labrador, Canada n.d; United States Bankruptcy Court Southern District of Illinois n.d). It may therefore be beneficial for the Hong Kong judiciary to tailor-make its guideline that corresponds to the legal culture in Hong Kong, so that laypeople can deal with legal signs better on their own.

Introducing unrepresented litigants to the basic manners of litigation is only one step towards facilitating their access to the legal system, and what needs to be done further is to map the ideological gap laypeople seem to have towards the law - that justice is largely based on the narration of truth with the help of judges. Their vision of justice leads them to underestimate the importance of procedures and methods of argumentation in the common law courtroom. Without understanding how narratives are practiced and evidence are presented in the courtroom, unrepresented litigants may be severely disadvantaged. An early introduction to the legal semiotics of these areas may assist lay litigants' case preparation. 
It is true that the suggestions may address only some of the problems unrepresented litigants encounter in court. A major issue lies in their unfamiliarity with legal semiotics in substantive law and advocacy. As Ross (Ross 2005: 5) recognizes, "there is no quick way to learn the skills of advocacy" - it takes years of training on the job. The dilemma is that unrepresented litigant's contact with law is usually brief, so immersing them in law for a long period of time seems rather impractical. Future research can look into the extent to which unrepresented litigants should know and learn about the law in order for their advocacy to be effective.

The problem with unrepresented litigation is as much about language and power as it is about wider social structures and ideologies, e. g., the availability of legal aid, cultural imaginary of the courtroom, and image of lawyers. It is our hope that the paper has (1) revealed the potential gap between legal and lay expectations of the law by highlighting the tensions between different practices of signs, and (2) shown how the use of semiotics can advance the socio-legal understanding of the communication gaps between laypeople and the law.

\section{References}

Apple Daily. 2012. Dramas need to be surreal. http://hk.apple.nextmedia.com/news/art/ 20120708/16494680 (accessed 3 August 2014).

Atkinson, J. M. \& P. Drew. 1979. Order in court: The organization of verbal interaction in judicial settings. London: Macmillan.

Boon, Andrew. 1999. Advocacy. London: Cavendish.

Cameron, C., E. Kelly \& E. Chiu. 2006. Judges' perspectives on the impact of self-representation in Hong Kong civil cases. Australian Journal of Asian Law 8. 261-286.

Chandler, Daniel. 2002. Semiotics: The basics. London: Routledge.

City Law School (London, England). 2010. Advocacy 2008-2009. Oxford: Oxford University Press.

Clarke, Catherine, Therese. 1991. Missed manners in courtroom decorum. Maryland Law Review 50(4). 946-1025.

Evans, Keith. 1993. The golden rules of advocacy. London: Blackstone.

Garner, Bryan A. \& Henry Campbell Black. 2009. Black's law dictionary. St. Paul, MN: West. Hutton, Christopher \& Kingsley Bolton. 2005. A dictionary of Cantonese slang: The language of Hong Kong movies, street gangs, and city life. Honolulu: University of Hawai'i Press.

Judiciary Administration. 2010. Legislative Council Panel on Administration of Justice and Legal Services Statistics on unrepresented litigants. Legislative Council Commission. http://www.legco.gov.hk/yr10-11/english/panels/ajls/papers/aj1122cb2-571-1-e.pdf (accessed 12 March 2012).

Kelly, Elsa. 2005. Litigants in person in civil proceedings: Part III recovering costs. Hong Kong Law Journal 35(2). 309-326. 
Kelly, Elsa \& Camille Cameron. 2003. Litigants in person in civil proceedings: Part II, solicitors' perspectives. Hong Kong Law Journal 33. 585-612.

Kelly, Elsa, Camille Cameron \& Wing Hong Chiu. 2006. Litigants in person in civil proceedings: Part IV barristers' perspectives. Hong Kong Law Journal 36. 519-552.

Klein, Linda. 2010. Report on the survey of judges on the impact of the economic downturn on representation in the courts. ABA Coalition for Justice. http://www.americanbar.org/con tent/dam/aba/migrated/JusticeCenter/PublicDocuments/CoalitionforJusticeSurveyReport. authcheckdam.pdf (accessed23 December 2013).

Leung, J. 2015. Lay Litigation Behaviour in Postcolonial Hong Kong Courtrooms. Language and Law / Linguagem e Direito 2(1). 32-52.

Lewis, Paul. 2007. Litigants in person and their difficulties in adducing evidence: A study of small claims in an English county court. International Journal of Evidence \& Proof 11. 24-48.

Luo, Zhufeng. 1987. Han yu da ci dian. Xianggang: San lian shu dian Xianggang fen dian.

Magistrates Court of Tasmania, Australia. 2014. Advice to self-represented parties. http://www.magistratescourt.tas.gov.au/going_to_court/advice_to_self-represented_ parties

McElhaney, James W. 1987. McElhaney’s trial notebook. Chicago: Section of Litigation, American Bar Association.

Mileski, Maureen. 1970-1971. Courtroom encounters: An observation study of a lower criminal court. Law \& Society Review 5. 473-538.

Moorhead, R. \& M. Sefton. 2005. Litigants in person: Unrepresented litigants in First Instance Proceedings. Department of Consitutional Affairs, London. https://www.law.cf.ac.uk/research/pubs/repository/1221.pdf (accessed 23 December 2013).

$\mathrm{Ng}, \mathrm{K} . \mathrm{H} .2009$. The common law in two voices: Language, law, and the postcolonial dilemma in Hong Kong. Stanford, CA: Stanford University Press.

Provincial Court of Newfoundland and Labrador, Canada. n.d. Etiquette \& procedures. http://www.court.nl.ca/provincial/goingtocourt/etiquette.html (accessed 5 August 2014).

Rhines, LaTanya D. 1995. Harassment of witnesses by attorneys. Journal of the Legal Profession 20. 331-342.

Ross, David. 2005. Advocacy. Cambridge: Cambridge University Press.

Saussure, Ferdinand de. 1983 [1916]. Course in general linguistics, Roy Harris (trans.). London: Duckworth.

Schachner, Robert W. \& Marvin Quittner. 2000. How and when to be your own lawyer. Garden City Park, NT: Avery.

Sherr, Avrom. 1993. Advocacy. London: Blackstone Press.

United States Bankruptcy Court Southern District of Illinois. n.d. Courtroom etiquette. http://www.ilsb.uscourts.gov/sites/default/files/CrtEtiquette.pdf (accessed 3 August 2014).

Wilkinson, Michael. 2000. Introduction. In M. Wilkinson \& B. Jane (eds.), Reform of the civil process in Hong Kong, 1-62. Hong Kong: Butterworths Asia.

Wilkinson, Michael, Vandana Rajwani \& Raymond Pierce. 2007. Advocacy and the litigation process in Hong Kong. Hong Kong: Lexis Nexis. 